\title{
The Impact of Macroeconomic and Corporate Governance Factors on Firm Value of Taiwanese Green Technology Industry: A Consideration of Differential Slope
}

\author{
Chien Jen, Wang ${ }^{1}$ \\ ${ }^{1}$ Department of International Trade, Takming University of Science and Technology, Taipei, Taiwan, R.O.C. \\ Correspondence: Chien Jen, Wang, Department of International Trade, Takming University of Science and \\ Technology, Taipei, Taiwan, R.O.C. Tel: 886-2-2658-5801. E-mail: chienjen@takming.edu.tw
}

Received: Apri 2, 2014

Accepted: April 22, 2014

Online Published: June 25, 2014

doi:10.5539/ijef.v6n7p157

URL: http://dx.doi.org/10.5539/ijef.v6n7p157

\begin{abstract}
Presently, the Taiwanese government is emphasizing the development of the green energy industry to lower the country's dependence on oil imports and to conserve Taiwan's environment. Green energy is considered to be an emerging and favored industry. This paper uses pooled estimation regression and Differential Slope Estimation to explore the relevant key factors of macroeconomics and corporate governance that affect firm value in Taiwan's green technology industry. Results suggest that when the return on equity is high, the firm's stock price increases as well. The TCRI, which is indicative of a firm's credit rating was found to be significantly and negatively related to stock price. Therefore, a lower credit rating has a higher stock price. In addition, our analysis also showed that both the foreign investor stockholding rate and board size have a significant and positive relationship with stock price. More foreign investors and a larger board of directors may increase the execution and performance of the company's corporate governance, thereby raising the firm's stock price.
\end{abstract}

Keywords: pooled estimation, Differential Slope Estimation, corporate governance, macroeconomic factors, green technology industry

\section{Introduction}

Accurate evaluation of firms is essential for investors, and many key factors can affect a firm's value. Generally, these factors can be divided into company's internal factors and outward macroeconomic factors; both must be considered when establishing a firm's valuation. Much of the literature has noted that companies with high levels of transparency and public disclosure have low market risk and high stock values. Therefore, strengthening corporate governance is a very important step toward providing objective reference information for investors. The mechanism of corporate governance helps to strengthen an enterprise's operations and facilitates the pursuit of the greatest benefit to shareholders. A firm with sound corporate governance is more likely to initiate the useful, do away with the harmful, solve information asymmetry problems, and attract long-term capitals and international investors.

American researchers began to explore the issues of corporate governance in the 1930s. In 1999, the World Bank defined corporate governance as the way in which firms build up a mechanism to maximum the value of firm value under the regulations of law and contract. According to the Organization for Economic Cooperation and Development (OECD), corporate governance is a system in which a company uses its management and the authorities to both regulate and specify the rules and procedures it follows when making a decision. Historical financial events such as the Asian financial crisis in 1997, Enron in 2001, MCI WorldCom in 2002, and global financial crisis in 2008 all serve to highlight the importance of corporate governance and financial supervision. Therefore, strengthening corporate governance remains an international trend, particularly after the financial seaquake, and governments are actively endeavoring to build up corporate governance mechanisms now more than ever.

Berles and Means (1932) first proposed the concept of separation between ownership and management, and analyzed the differentiation of ownership and management in large corporations. The discussion of corporate governance has continued to attract the attention of researchers and practitioners. Yeh, Lee and Ko (2002) proposed that the intention of corporate governance is to find those people who have the right to manage the 
company, as well as allocating decision-making responsibility and resources that influence the firm's value. Yeh et al. (2002) focused mainly on the top-management of a corporation and expected to increase the benefits and prevent the drawbacks of corporate governance, as well as protecting the equity of shareholders.

Gompers, Ishii, and Metrick (2003) found that corporate governance is significantly related to firm valuation and net profit margin in the United States. La Porta et al. (2002) demonstrated that firms have greater access to external financing in countries with more effective legal protection for minority shareholders, resulting in broader and more valuable capital markets. Shleifer and Wolfenzon (2002) also found that firms tend to be larger, more valuable, and more numerous in countries with better investor protection. Gompers et al. (2003) confirmed that an investment strategy that purchased stocks of better-governed companies and sold stocks of poorly governed companies earned an abnormal return of $8.5 \%$ per year during the 1990s. Klapper and Love (2004) examined the relationship between corporate governance and performance in a cross-section of firms from 14 emerging markets by using a governance score (CLSA). They found that companies with higher governance standards have greater market valuation and better operating performance. Durnev and Kim (2005) also used a CLSA score to test the association between corporate governance and valuation for a sample of firms from 27 countries, and suggested that firms can increase shareholders' value by adopting higher levels of corporate governance in countries with weaker legal regimes.

Braga-Alves and Shastri (2011) constructed a composite index (NM6) by combining six proxies for the main governance practices and found that higher scores for this index are related to greater market value. They also noted that an investment strategy that purchased stocks of firms with high NM6 and sold stocks of firms with low NM6 would have earned abnormal returns of 10.68\% per year between 2001 and 2005. Most literature shows us that good governance is not only associated with higher equity returns, but also with higher firm value and better operating performance.

Enterprises face various kinds of risks, not only from the internal environment but also from the external environment. In addition to the corporate governance factors, a firm's value is also influenced deeply by outward macroeconomic factors. The systematic risk, drawn from hasty change of the external macro-economic environment, exerts a great influence on enterprise's performance. For instance, the volatilities of commodity prices, interest rates, and a country's financial policy describing systematic risk all could play a role in affecting a firm's performance. These factors cannot be obviously noted from financial statements. However, it is important for the enterprise to explore the impact of uncertainty on a firm's performance to evaluate firm value more exactly and further to engage in relative risk management. Bildersee and Roberts (1981) showed a security's systematic risk is sensitive to interest rate fluctuations. Abell and Krueger (1989) evidenced the interest rates and inflation were important macro-economic variables influencing the changes in systematic risk. Chan, Lee, and Yeh (2000) examined the relationship between systematic risk and stock return from 1992 to 1999 and showed regardless of the length of holding return (shorter or longer), the effects of systematic risk are significantly related to the asset returns for Taiwan listed companies. This point is further confirmed by empirical results of $\mathrm{Wu}$ and Wang (2008).

At present, valuations in the green technology industry have attracted the attentions of researchers and practitioners. Due to the increase in global warming and the subsequent weather changes, developing the green energy industry increasingly becomes the focus of global discussion. Research in green energy and regenerating energy is also increasing. Governments worldwide view green initiatives as favorable to sustain perpetual production and development. As a result, they invest many resources in research and development (R\&D) and adopt green policies to govern production. Taiwanese green technology initiatives are based on an established background of high-technology development and therefore, this country has the potential to develop into a major producer of green energy products. Taiwan's LED (Light Emitting Diode) industry, the second largest LED industry in the world (Japan being the largest), is representative of green energy product initiatives. Furthermore, the production of Taiwan's LED elements and backlight model is ranked first in the world - the production value was approximately USD 20 billion in 2009, and USD 55 billion in 2010. Taiwan's large, listed companies, including Taiwan Semiconductor Manufacturing (TSMC), Formosa Plastics (FPC) and HON HAI have all invested considerable capital in the production of LED lighting solutions. In addition, the creation of Original Brand Manufacturing (OBM) for Taiwan's LED firms can open more sales channels to further advance the Taiwanese LED industry in the global lighting market. This shows that the Taiwanese government pays attention to promoting this emerging industry and, on a greater scale, on developing the green technology industry in Taiwan. However, many factors can affect the firms' operating performance and their value. This paper attempts to explore the Taiwanese green technology industry, and understand the key factors that influence stable growth of green energy. This is done mainly from a macroeconomic and corporate governance point of view. The 
perpetual development and carbon reduction effects have a positive influence on human living environment.

In this paper, we utilize Taiwanese LED green energy firms as a sample to explore the impact of macroeconomic and corporate governance factors on firm value. In the process, we consider several important factors, including interest rates and customer price index from a macroeconomic perspective, and TCRI credit rating, director stockholding rate, foreign investor stockholding rate, and board size from a corporate governance perspective. While previous studies have used regression methods, the estimation method used in this study includes both a fixed effects model and a random effects model. The study also uses differential slope analysis to analyze whether the specific variable on a firm's value varies from company to company. This was not well addressed in previous studies. The empirical results showed that when the return on equity is high, the firm's stock price increases as well. The firm's credit rating (TCRI) is significantly and negatively related to stock price. A higher foreign stockholding rate and greater board size improve the execution and performance of the company.

The remainder of the paper is organized as follows. Section 2 introduces the empirical model. Section 3 discusses the methodology and data. Section 4 presents the empirical results of the analysis; and Section 5 summarizes and concludes the paper.

\section{Empirical Model}

Recently, global governments have placed a greater emphasis on green technology industry as the most favored for growth. Based on history and against a background of groundbreaking high-technology development, Taiwan has the potential to develop as a major producer of green technology products. This paper explores the impact of macroeconomic and corporate governance factors on firm value in Taiwan's green technology industry. Given the relevant variables, the empirical model used for this paper can be estimated as Equation (1).

$$
P_{i, t}=\alpha_{i}+\beta_{1} R O E_{i, t}+\beta_{2} T C R I_{i, t}+\beta_{3} F_{i, t}+\beta_{4} D_{i, t}+\beta_{5} B S_{i, t}+\beta_{6} C P I_{t}+\beta_{7} I R_{t}+\varepsilon_{i, t}
$$

where $P_{i, t}$ represents the quarterly stock closing price of the $i$ th green firm at time $t$; ROE $E_{i, t}$ is the return on equity of the $i$ th green firm at time $t$ representing the firm's profit performance; TCRI $I_{i, t}$ is the credit rating of the $i$ th green firm at time $t$, which has been divided into Degree 1-9 (Degree 9 indicates the highest credit risk and Degree 1 indicates the lowest credit risk); $F_{i, t}$ is the foreign investor's stockholding rate of the $i$ th green firm at time $t ; D_{i, t}$ is the director stockholding rate of the $i$ th green firm; $B S_{i, t}$ is the number of directors on the board; $C P I_{t}$ expresses the customer price index $(2006=100)$; and $I R_{t}$ is the bank interest rate (the average loan rate of Taiwan five banks); and $\varepsilon_{i, t}$ is the disturbance term.

\section{Methodology and Data}

In this paper, we employ pooled estimation regression, which combines the cross-sectional and time series data. The methodology includes the Fixed-effects model (FEM) and the Random-effects model (REM), and further uses the Hausman test to judge the suitability of the models. Further, to differentiate and gauge individual firm behavior, we use Differential Slope Estimation (Wald test) to investigate the estimation coefficient $\beta_{k}$ of the FEM and REM for the specific firm. Pooled estimation has the advantages of providing numerous data observations and blending cross-sectional and time series data to improve the efficiency of econometric estimates (Hsiao, 1985). This methodology yields reliable coefficient estimates when unobservable individual fixed or random effects exist. Two models for fixed and random effects can respectively be written as follows:

Fixed Effects Model:

$$
Y_{i t}=\alpha_{i}+\sum_{k=1}^{K} \beta_{k} X_{k i t}+\varepsilon_{i t}
$$

Random Effects Model:

$$
Y_{i t}=\left(\alpha_{0}+\mu_{i}\right)+\sum_{k=1}^{K} \beta_{k} X_{k i t}+\varepsilon_{i t}
$$

where $i=1, \ldots, \mathrm{N}$, and $t=1, \ldots, \mathrm{T}$, and $\mathrm{N}$ and $\mathrm{T}$ respectively denote the cross-sectional and time dimensions of the panel. $Y_{i t}$ and $X_{k i t}$ represent the dependent variable and independent variable, respectively. Individual effects are $\alpha_{i}$ when fixed, and $\left(\alpha_{0}+\mu_{i}\right)$ when random and normally distributed. $\varepsilon_{i t}$ is the disturbance term $\sim i d\left(0, \sigma^{2}\right)$.

The primary difference between the FEM and REM relates to whether the disturbance term $\varepsilon_{i t}$ is identical and independent (iid). FEM has fixed constants to illustrate data characteristics, so $\varepsilon_{i t}$ is $i i d$. However, the REM constants are random, so it is unnecessary for $\varepsilon_{i t}$ to be iid. (Note 1) Hausman (1978) proposed a method for judging the applicability of the FEM or REM. More specifically, the Hausman test is to be used to examine whether the constant $\left(\mu_{i}\right)$ and explanatory variables $\left(X_{k i t}\right)$ are correlated. If the constant $\left(\mu_{i}\right)$ significantly 
correlates with explanatory variables $\left(X_{k i t}\right)$, then the estimation results of FEM would be valid, and the FEM provides the best-fitting model. If $\left(\mu_{i}\right)$ is not significantly correlated with $\left(X_{k i t}\right)$, the best-fitting model is provided by REM.

We sampled 21 Taiwanese green energy LED firms listed on the Taiwan Security Exchange Corporation (TSEC) as subjects in this research. The research period ranges from 2001 Q1 to 2012 Q4, providing 586 total quarterly observations. All data are from the Taiwan Economic Journal (TEJ) databank. Data source and measurement information are showed in Table 1.

Table 1. Data source and measurement

\begin{tabular}{llll}
\hline Notation & Variable & Measurement & Source \\
\hline$P_{i, t}$ & Stock Price & Quarterly Stock Closing Price & TEJ \\
$R O E_{i, t}$ & Return on Equity & Quarterly Return on Equity & TEJ \\
$T C R I_{i, t}$ & Credit Rating Index & Credit Rating Index (Degree 1-9) & TEJ \\
$F_{i, t}$ & Foreign Investor Stock Holding Rate & Foreign Investor Stock Holding Rate & TEJ \\
$D_{i, t}$ & Directors Stock Holding Rate & Directors Stock Holding Rate & TEJ \\
$B S_{i, t}$ & Board Size & Number of Directors on the Board & TEJ \\
$C P I_{t}$ & Customer Price Index & Customer Price Index (2006=100) & TEJ \\
$I R_{t}$ & Bank Interest Rates & Taiwan Five Banks Average Loan Rates & TEJ \\
\hline
\end{tabular}

\section{Empirical Results}

In this section, we present the empirical findings of the estimation regression showed in Eq.(1) (see Table 2 for a summary of these findings). Results of the Hausman test show that the Fixed Effects Model (FEM) provides the greatest explanatory power, so we utilize the FEM to perform the Differential Slope Estimation. Tables 3 and 4 present the estimation results of the Differential Slope Estimation and FEM different in director stockholding rate and foreign investor stockholding rate, respectively.

Table 2. Estimation results of panel regression-green technology firms

\begin{tabular}{|c|c|c|c|c|}
\hline \multirow[b]{2}{*}{ Explanatory Variable } & \multicolumn{2}{|c|}{ Fixed Effects Model } & \multicolumn{2}{|c|}{ Random Effects Model } \\
\hline & Coefficient & t-Statistic & Coefficient & t-Statistic \\
\hline & -45.061 & -1.35 & $-66.152 * *$ & -2.07 \\
\hline$R O E_{i, t}$ & $17.845^{* * *}$ & 16.54 & $17.614 * * *$ & 16.54 \\
\hline$T C R I_{i, t}$ & $-3.966 * * *$ & -3.42 & $-3.943 * * *$ & -3.44 \\
\hline$F_{i, t}$ & $0.287 * *$ & 2.17 & $0.227 *$ & 1.79 \\
\hline$D_{i, t}$ & $-0.458 * *$ & -2.04 & -0.206 & -1.04 \\
\hline$B S_{i, t}$ & $0.591^{*}$ & 0.57 & $0.574 *$ & 0.56 \\
\hline$C P I_{t}$ & $0.872 * * *$ & 2.96 & $1.131 * * *$ & 4.05 \\
\hline$I R_{t}$ & 0.243 & 0.35 & -0.107 & -0.15 \\
\hline Observatians & \multicolumn{2}{|l|}{586} & \multicolumn{2}{|l|}{586} \\
\hline Adjusted $R^{2}$ & \multicolumn{2}{|l|}{0.687} & \multicolumn{2}{|l|}{0.459} \\
\hline$A I C$ & \multicolumn{2}{|l|}{8.538} & \multicolumn{2}{|l|}{-} \\
\hline$S B C$ & \multicolumn{2}{|l|}{8.747} & \multicolumn{2}{|l|}{-} \\
\hline$F$-statistic & \multicolumn{2}{|c|}{$48.70 * * *(0.000)$} & \multicolumn{2}{|c|}{$72.03 * * *(0.000)$} \\
\hline Hausman test $x^{2}(7)$ & \multicolumn{2}{|c|}{$62.64 * * *(0.000)$} & & \\
\hline
\end{tabular}

Note. Dependent variable is stock closing price of green company. The testing results show that Fixed Effects Model (FEM) has the largest explanatory power. *significant at $10 \%$ level; ** significant at $5 \%$ level; *** significant at $1 \%$ level.

Table 2 shows that the coefficient of return on equity is significantly and positively related to stock price, indicating that the estimation of ROE is an important determinant of a green technology firm's stock price. ROE is an indicator of a company's profit performance. Specifically, we found that when the ROE is high, the firm's stock price increases as well. However, the TCRI, which is indicative of a firm's credit rating (good or bad), was found to be significantly and negatively related to stock price. The lower credit degree indicates a lower credit risk. Therefore, a lower credit rating has a higher stock price. Using the credit rating mechanism of the TCRI is 
also helpful for outer governance controls, which may promote the governance quality for a company. The use of a credit rating as an indicator of corporate governance has not been discussed very much in past literature, so in this paper, we explore the relationship between a company's credit rating and stock price. In addition, our analysis also showed that the foreigner investor stockholding rate $(F)$ has a significant and positive relationship with stock price, indicating that a higher percentage of foreigner stockholding may increase the execution and performance of the company's corporate governance. Foreign institutional investors' researching groups positively appraise a company with sound management; thus, high foreign investor stockholding may help to raise a company's stock price. Board size $(B S)$ is also the focus of corporate governance. Consistent with the findings of Dalton et al. (1999), the analysis showed that the board size control variable has a significant and positive relationship with stock price, indicating that larger board of directors leads to greater efficiency and effectiveness in the supervisory control of the company's management, thus helping to raise stock price. However, the director stockholding rate $(D)$ has a significant and negative relationship with stock price. This probably indicates that most green technology firms may increase (decrease) their director stockholding separately before prosperous (depressive) economic conditions.

Because macroeconomic factors have a considerably higher correlation with stock price, we also consider important macroeconomic factors to explore their correlation with firm value. For instance, customer price index (CPI) is also significantly and positively related to stock price. However, interest rates were shown to be insignificant. The probable reason is that Taiwanese interest rates have been moderated by the government and, therefore, exhibit a smooth, fluctuating tendency. As a result, they were shown to be insignificant.

Table 3. Estimation of differential slope Method-FEM-Different in director holding $D_{i, t}$

\begin{tabular}{|c|c|c|c|c|c|}
\hline \multicolumn{6}{|c|}{ Dependent Variable: $S P$} \\
\hline \multicolumn{6}{|c|}{ Common Slope } \\
\hline Variable & Coefficient & p-value & Variable & Coefficient & p-value \\
\hline$R O E_{i, t}$ & 12.924 & $0.000 * * *$ & $T C R I_{i, t}$ & -6.779 & $0.000^{* * *}$ \\
\hline$F_{i, t}$ & 0.241 & $0.067^{*}$ & $C P I_{t}$ & 0.421 & $0.075^{*}$ \\
\hline$I R_{t}$ & -0.178 & 0.770 & $B S_{i, t}$ & 1.534 & $0.091 *$ \\
\hline \multicolumn{6}{|c|}{ Different Slope } \\
\hline OPTOTECH & -1.426 & $0.021 * *$ & EVERLIGHT & -10.922 & $0.000 * * *$ \\
\hline UNITY & -1.913 & $0.050^{* *}$ & BRIGHT & -1.968 & $0.000 * * *$ \\
\hline CHIALIN & -4.460 & $0.001 * *$ & GSEO & 9.129 & $0.000 * * *$ \\
\hline JENTECH & 2.025 & $0.139^{*}$ & SAS & -1.988 & $0.000 * * *$ \\
\hline PTTC & -2.085 & $0.019^{* *}$ & YTEC & -2.021 & $0.015^{*}$ \\
\hline THIEL & -5.523 & $0.003 * *$ & $\mathrm{AOC}$ & -2.858 & $0.000 * * *$ \\
\hline LIGITEK & -1.758 & $0.009^{* *}$ & ACME & -2.613 & $0.003 * *$ \\
\hline Adjusted $R^{2}$ & & & 0.785 & & \\
\hline AIC & & & 8.193 & & \\
\hline$S B C$ & & & 8.551 & & \\
\hline D-W Stat. & & & 0.906 & & \\
\hline
\end{tabular}

Note. Dependent variable is firm stock price. ${ }^{* * *},{ }^{* *}$ and* denote statistically significant at $1 \%, 5 \%$ and $10 \%$ level, respectively.

To further explore the significance of a specific firm's individual behavior, we used the Differential Slope Estimation. Table 3 and 4 show the estimation results of this method. In Table 3, we discovered mixed results for the influence of director stockholding rate on stock price. Although fourteen out of 21 companies had significant relationship between the variables, the same relationship for the other seven companies was non-significant. Among the fourteen firms for which the relationship was significant, OPTOTECH (2340), twelve companies had a negative association between director stockholding and firm value. For the other two companies for which the relationship was significant and positive. This result indicates that most green technology firms probably increase (decrease) their director stockholding separately before prosperous (depressive) economic conditions. 
Table 4. Estimation of differential slope Method-FEM-Different in foreigner holding $F_{i, t}$

\begin{tabular}{|c|c|c|c|c|c|}
\hline \multicolumn{6}{|c|}{ Dependent Variable: SP } \\
\hline \multicolumn{6}{|c|}{ Common Slope } \\
\hline Variable & Coefficient & p-value & Variable & Coefficient & $p$-value \\
\hline$R O E_{i, t}$ & 13.741 & $0.000 * * *$ & $T C R I_{i, t}$ & -5.269 & $0.000 * * *$ \\
\hline$D_{i, t}$ & -0.203 & 0.340 & $C P I_{t}$ & 0.758 & $0.005^{* *}$ \\
\hline$I R_{t}$ & -0.147 & 0.805 & $B S_{i, t}$ & 0.712 & $0.100 *$ \\
\hline \multicolumn{6}{|c|}{ Different Slope } \\
\hline OPTOTECH & -0.286 & $0.100 *$ & EVERLIGHT & 1.658 & $0.000 * * *$ \\
\hline BRIGHT & 2.172 & $0.018 * *$ & TAIWANOASIS & 63.816 & $0.064^{*}$ \\
\hline CHIALIN & 397.427 & $0.000 * * *$ & GSEO & 91.386 & $0.000 * * *$ \\
\hline SAS & 1.774 & $0.030^{* *}$ & YTEC & 2.679 & $0.017 * *$ \\
\hline THIEL & 63.567 & $0.000^{* * *}$ & $\mathrm{AOC}$ & 2.800 & $0.002 * *$ \\
\hline LIGITEK & -9.896 & $0.004 * *$ & ACME & 9.742 & $0.037 * *$ \\
\hline Adjusted $R^{2}$ & & & 0.783 & & \\
\hline AIC & & & 8.202 & & \\
\hline$S B C$ & & & 8.560 & & \\
\hline$D-W$ Stat. & & & 0.830 & & \\
\hline
\end{tabular}

Note. Dependent variable is firm stock price. ${ }^{* *},{ }^{* *}$ and ${ }^{*}$ denote statistically significant at $1 \%, 5 \%$ and $10 \%$ level, respectively.

Table 4 shows the results of the Differential Slope Estimation as a means to reveal differences in foreign investor stockholding. For 10 out of 21 companies, there was a significant and positive relationship between foreign investor stockholding and firm value, indicating that an increase in foreign investor stockholding can yield an increase in energy firm stock prices. Large, green energy firms, such as CHIALIN (3310), TAIWANOASIS (3066), and GSEO (3406), each have larger marginal effects of foreign investor stockholding on firm value. This result reveals that a higher percentage of foreign stockholders may increase the execution and performance of the company's corporate governance. As a result, if a company is managed well, its stock price will rise. These empirical results are consistent with our intuition.

\section{Conclusion}

Presently, the Taiwanese government is emphasizing the development of the green energy industry to lower the country's dependence on oil imports and to conserve Taiwan's environment. Green energy is considered to be an emerging and favored industry. Due to its green initiatives, Taiwan has excellent R\&D technology and manufacturing capabilities compared to other countries. This could accelerate the country's green energy development. Meanwhile, Taiwan is already a global leader in the development of technology that promotes a greener world, namely the LED. Given its economic and environmental benefits, all countries favor green energy as an industry with potential for great market value. These factors have brought national focus to the issue of corporate governance. Green energy firms with sound corporate governance not only create greater profit opportunities for shareholders, but also increase their capability to cope with financial emergencies.

This paper has used pooled estimation regression to explore the relevant key factors of macroeconomics and corporate governance that affect firm value in Taiwan's green technology industry. While previous studies have employed regression methods to explore the relationship between corporate governance factors and firm value, this study uses panel data and differential slope analysis-methods that were rarely used in previous studies. The estimation results revealed that when the return on equity is high, the firm's stock price increases as well. The TCRI, which is indicative of a firm's credit rating was found to be significantly and negatively related to stock price. Therefore, a lower credit rating has a higher stock price. In addition, consistent with Wu and Chen (2007), they found that the external governance mechanism, indexed by the holdings of outside institutions, exhibits a positive relationship with market returns. Our analysis also showed that both the foreign stockholding rate and board size have a significant and positive relationship with stock price. More foreign investors and a larger board of directors may increase the execution and performance of the company's corporate governance, thereby raising the firm's stock price. However, the director stockholding rate has a significant and negative relationship with stock price. This probably indicates that most green technology firms may increase (decrease) their director stockholding separately before prosperous (depressive) economic conditions. As opposed to other existing literature, this paper uses differential slope estimation to observe the marginal effects of the relationship among the variables, and reveal different characteristics and features of each green energy firm. The results presented 
here can serve as an important reference for investment institutions to construct their portfolios, and provide insights for researchers and governments engaged in developing the green technology industry.

\section{Acknowledgments}

I would like to thank professors Jang W. Y. and Chang Y. for their helpful comments and suggestions. All remaining errors are my own.

\section{Reference}

Abell, J. D., \& Krueger, T. M. (1989). Macroeconomic Influences on Beta. Journal of Economics and Business, 41, 185-193. http://dx.doi.org/10.1016/0148-6195(89)90016-7

Berles, A., \& Means, G. (1932). The Modern Corporation and Private Property. Transaction Publishers.

Bildersee, J. S., \& Roberts, G. S. (1981). Beta Instability When Interest Rate Levels Change. Journal of Financial and Quantitative Analysis, 16, 375-381. http://dx.doi.org/10.2307/2330244

Braga-Alves, M. V., \& Shastri, K. (2011). Corporate Governance, Valuation, and Performance: Evidence from a Voluntary Market Reform in Brazil. Financial Management, 40(1), 139-157. http://dx.doi.org/10.1111/j.1755-053x.2010.01137.x

Chan, A. L., Lee, W. C., \& Yeh, C. K. (2000). The Empirical Study of the Relation between System Risk, Size and Stock Return. Web Journal of Chinese Management, 3(4), 1-14.

Dalton, D. R., Daily, C. M., Johnson, J. L., \& Ellstrand, A. E. (1999). Number of Directors and Financial Performance: a Meta-Analysis. Academy of Management Journal, 42, 674-686. http://dx.doi.org/10.2307/256988

Durnev, A., \& Kim, H. (2005). To Steal or Not to Steal: Firm Attributes, Legal Environment, and Valuation. Journal of Finance, 60, 1461-1493.

Gompers, P. A., Ishii, J. L., \& Metrick, A. (2003). Corporate Governance and Equity Prices. Quarterly Journal of Economics, 118, 107-155. http://dx.doi.org/10.2139/ssrn.278920

Hausman, J. A. (1978). Specification Tests in Econometrics. Econometrica, 46, 1251-1271. http://dx.doi.org/10.2307/1913827

Hsiao, C. (1985). Benefits and Limitations of Panel Data. Econometric Reviews, 4, 121-174. http://dx.doi.org/10.1080/07474938508800078

Klapper, L. F., \& Love, I. (2004). Corporate Governance, Investor Protection, and Performance in Emerging Markets. Journal of Corporate Finance, 10, 703-728. http://dx.doi.org/10.2139/ssrn.303979

La Porta, R., Lopez-de-Silances, F., Shleifer, A., \& Vishny, R. (2002). Investor Protection and Corporate Valuation. Journal of Finance, 57, 1147-1170. http://dx.doi.org/10.2139/ssrn.192549

Shleifer, A., \& Wolfenzon, D. (2002). Investor Protection and Equity Markets. Journal of Financial Economics, 66, 3-27. http://dx.doi.org/10.2139/ssrn.244520

Wald, A. (1943). Test of Statistical Hypotheses Concerning Several Parameters When the Number of Observations is Large. Transactions of the American Mathematical Society, 54(3), 426-482. http://dx.doi.org/10.1090/s0002-9947-1943-0012401-3

Wu, W., \& Chen, C. (2007). Relationship Among Corporate Governance, Agency Problem, and the Performances of Mergers and Acquisitions: Case of Listed Companies in Taiwan. Journal of Macau University of Science and Technology, 1(2), 71-93.

Wu, P. C., \& Wang, C. J. (2008). The Effect of Systematic Risk on Equity Valuation: An Extended Application of the Ohlson Equity Valuation Model. Journal of Humanities and Social Sciences, 4(1), 69-81.

Yeh, Y. H., Lee, T. S., \& Ko, C. (2002). Corporate Governance and Rating System. SUNBRIGHT Publishers.

\section{Note}

Note 1. See Hsiao (1985). 


\section{Appendix A. Fixed Effects of Green Technology Firms}

\begin{tabular}{llll}
\hline \multicolumn{3}{c}{ Company Name } \\
\hline 1 & Company Code & Name & Fixed Effects \\
2 & 2301 & LTC & -30.200 \\
3 & 2340 & OPTOTECH & -5.627 \\
4 & 2393 & EVERLIGHT & -5.825 \\
5 & 2426 & TYNTEK & -4.215 \\
6 & 2486 & ICHIUN & -4.386 \\
7 & 2499 & UNITY & -5.237 \\
8 & 3031 & BRIGHT & -3.524 \\
9 & 3066 & TAIWANOASIS & 7.156 \\
10 & 3310 & CHIALIN & 28.177 \\
11 & 3406 & GSEO & 92.598 \\
12 & 3531 & SHIANYIH & -5.905 \\
13 & 3653 & JENTECH & 67.819 \\
14 & 5483 & SAS & -0.804 \\
15 & 6164 & LEDTECH & -14.147 \\
16 & 6224 & PTTC & -8.655 \\
17 & 6226 & PARALIGHT & -4.902 \\
18 & 6261 & YTEC & -12.782 \\
19 & 6271 & THIEL & 17.749 \\
20 & 6289 & AOC & 24.282 \\
21 & 8111 & LIGITEK & -1.519 \\
\hline & 8121 & ACME & 7.018 \\
\hline
\end{tabular}

Source: This Study.

\section{Copyrights}

Copyright for this article is retained by the author(s), with first publication rights granted to the journal.

This is an open-access article distributed under the terms and conditions of the Creative Commons Attribution license (http://creativecommons.org/licenses/by/3.0/). 